\title{
Analysis of Low Student Achievement in Fifth Grade State Elementary School 1 Barejulat
}

\author{
"Siska Dilvina, A. Hari Witono, Safruddin \\ Elementary School Teacher Education Study Program, FKIP, University of Mataram. Jl. \\ Majapahit No. 62, Mataram, Indonesia. Postal code: 83125 \\ *Corresponding Author e-mail: dilvinasiska@gmail.com
}

Received: August 2021; Revised: September 2021; Published: December 2021

\begin{abstract}
This study aimed to determine the internal and external factors that cause low learning achievement of fifthgrade students at SDN 1 Barejulat. Internal factors include intelligence, interests, talents, and motivation, while external factors include family, school, and community. This study uses a qualitative approach with a case study method. Data collection techniques were carried out through interviews, observations, and documentation studies. Instrument using interview sheet. The data analysis technique used is data reduction, data presentation, conclusion, or verification. Test the validity of the data using extended observations, increasing persistence, source triangulation, technique triangulation, and time triangulation. The subjects of this study were fifth-grade students. The results of this study indicate that students who get low learning scores, are caused by the lack of intelligence, interests, talents, and motivations possessed by both of them. Besides that it is also influenced by the family environment, school environment, and environment. Low student motivation is due to students' high sense of laziness in doing assignments and the lack of motivation given by parents. The family environment is very closely related to learning achievement. This is related to the lack of attention and warmth in the students' families themselves. Efforts made by teachers in improving the learning achievement of fifth-grade students at SDN 1 Barejulat are by creating a class atmosphere that is thick with the spirit to compete, and guiding students by holding additional lessons. In addition, the teacher also tries to communicate with the parents of these students so that they pay more attention to their children's learning activities.
\end{abstract}

Keywords: analysis; low learning outcomes; elementary school

How to Cite: Dilvina, S., Witono, A., \& Safruddin, S. (2021). Analysis of Low Student Achievement in Fifth Grade of Elementary School. Prisma Sains : Jurnal Pengkajian Ilmu dan Pembelajaran Matematika dan IPA IKIP Mataram, 9(2), 168-176. doi:https://doi.org/10.33394/j-ps.v9i2.4150

\section{INTRODUCTION}

One of the parameters used to measure educational success is student achievement (Goddard, et al., 2015). Society, students and teachers always want good learning achievements (Rubie-Davies, et al., 2010; Yustiqvar, et al., 2019). Student achievement is influenced by many factors, which broadly consist of two factors, namely internal factors and external factors (Amri, 2018). Internal factors come from within students, such as learning discipline, physiological conditions (physical condition of students), psychological conditions (intelligence, talent, interest, motivation). While external factors are factors that come from outside the student, for example, environmental factors, instrumrnt tools (curriculum, learning methods, facilities and facilities, and teachers/teachers (Syafi'I, et al., 2018).

In order to produce quality human resources, a quality education process is also needed (Sudarsana, 2016). Quality education is shown from the learning achievements obtained by students through a good learning process (Ghozali, 2017). However, not every student gets satisfactory learning achievement while participating in learning activities as expected. Sometimes they have difficulty in learning, causing low learning achievement (Ramdani, et 
al., 2021). This is in accordance with the results of an initial field study conducted at SDN 1 Barejulat, which showed that there were still students who experienced low learning achievement. Researchers were interested in examining low learning achievement in class $\mathrm{V}$ at SDN 1 Barejulat.

Learning achievement is the end of the teaching and learning process, which is useful as a measuring tool for the extent to which learning subjects are able to master the material that the teacher has delivered. Not only that, learning achievement can reflect the success of a teacher in carrying out the learning process (Hadisaputra, et al., 2019). Good student learning achievement will be a provision for them to face 21st century guidance which must have HOTS abilities (Gunawan, et al., 2021)

Student achievement starting from education in the family, especially parents, is one of the many factors affecting achievement at school (Andri, et al., 2017). The success rate of students in learning the subject matter is expressed by their learning achievements (Safitri and Yuniwati, 2019). Learning achievement is intended as the level of learning success which is expressed in the form of scores and changes in good behavior after someone has carried out the learning process. According to Ansori, et al (2016), learning achievement is a result conducting an assessment expressed by numbers or symbols, all of which are about the progress or learning outcomes of students during a specific period. In addition, Rosyid, et al (2019) provides an understanding of learning achievement, namely the results achieved by someone in a learning effort as stated in the report card.

Learning achievement is said to be perfect if three aspects are met, namely: cognitive, affective and psychomotor. On the contrary, it is said to be unsatisfactory if someone has not met the targets in these three criteria (Andri, et al., 2017). The low learning achievement itself is influenced by internal factors including physical and psychological factors, while external factors are family factors, school factors, and community factors (Rosyid, et al., 2019). In the education process, especially in the student learning system, it is expected to improve learning achievement with good learning. All students become graduates who are intellectual, creative, and become candidates for professional and personally responsible educators.

In general, internal and external factors that affect low learning achievement are interrelated with each other, so that they are inseparable. The task of teachers in learning in schools is how-to guide and direct the abilities of students based on their talents and interests, which include cognitive, affective, and psychomotor aspects, so that they are expected to become intelligent, faithful, and pious human beings and useful for the nation and state. This study aims to determine the internal and external factors that cause low learning achievement of fifth-grade students at the State Elementary School 1 Barejulat.

\section{METHOD}

This research uses a case study method with a qualitative approach (Arikunto, 2013). A qualitative research approach is used in this study because this study focuses on two subjects, namely RS and LT. Subject selection is based on documentation of student learning outcomes, found with achievement consistency at the lowest 3rd rank, and willing to cooperate, explore subject problems including class teachers, people subject's parents, and close friends.

This type of research data consists of primary data and secondary data. According to Sutrischastini and Riyanto (2015) primary data is information obtained by reseaechers through direct investigation of the symptoms or from the source, while secondary data is from the source, while secondary data is information obtained by a researcher through other sources, both oral and written.

Data collection techniques using observation sheets, interviews, documentation. Instrument using interview sheet. The data analysis technique uses three activity lines, namely data collection, data reduction, data presentation and conclusion drawing. The 
validity of the data in qualitative research includes four criteria: credibility, transferability, dependability, confirmability.

\section{RESULTS AND DISCUSSION}

Several factors influence low learning achievement, including internal and external factors (Hur, et al., 2016). Internal factors are factors that exist within the individual himself. As for what is included in the internal factors, including physical factors of students, attention, interest, motivation, level of intelligence, fatigue factor, and others. Meanwhile, external factors are factors that exist outside the individual itself. These factors include family environment, school environment factors, community environmental factors, and time factors.

This is in accordance with research conducted by Tokan and Imakulata (2019) which states that several factors are suspected to be the cause of low student achievement, including learning behavior, learning motivation, lecturer competence, supporting facilities and infrastructure, use of Information Technology (IT) which excessive, parental support and other factors. In addition, Zhu and Yang (2012) explain motivation as a psychological tendency and internal drive, which stimulates and regulates the actions of an organism.

\section{Factors Causing Low Learning Achievement}

\section{a. Internal factors}

1. Intelligence

In everyday life, students who have low academic achievement tend to prefer to play rather than study, and their peers often pick up student 1 to play until they lose track of time, while LT prefers to watch TV and play with their friends. RS and LTI parents also don't have a problem with this, and they tend to give their children the freedom to do anything without supervision. As a result, children's academic grades are not so good, even RS and LT are students who are not competent in their class. This is in line with Chulsum's opinion (2017) that the environment has a significant role in individual education. An unfavorable environment will certainly produce poor intellectual abilities as well.

2. Interest

Based on the results of the study, it was stated that the interest of the hospital and LT towards science subjects so that when science subjects took place the hospital tended to follow these lessons well. However, in addition to science subjects, hospital and LT will pay more attention to these lessons if activities are carried out using interesting learning media. The results of this study are in accordance with Sirait (2016), opinion, which defines interest as a persistent tendency to pay attention and remember an activity. If someone is interested in a particular activity, he will pay attention continuously, accompanied by a sense of pleasure.

3. Talent

Based on the results of research RS and LT do not have a prominent talent in him. This is obtained from various sources, namely interviews and observations. In their daily activities, the hospital and LT have not shown their expertise in certain fields so their talents have not been seen significantly. Fadillah (2016) states that talent is the potential possessed by someone who has brought since birth. Therefore, the hospital has not yet shown its potential.

4. Motivation 
Based on the research results, hospitals and LTs have low learning motivation. This can be seen from the high feeling of laziness in hospitals and LTs in doing assignments, both at school and at home. In addition, RS and LT also rarely ask teachers or friends of RS and LT about material that RS and LT have not understood. RS and LT also don't want to express their opinion during group learning activities so that the scores that RS and LT get are more on average.

The results of this study explain that the intrinsic motivation of RS and LT is more dominant in influencing the learning performance of RS and LT. This is in line with Tokan and Imakulata (2019) opinion, which states that the more significant motivation for students is intrinsic motivation. Hilda, et al (2004) also found intrinsic motivation as a drive that comes from within a person, related to satisfaction. Danim (2012) states that motivation is a meaningful attitude and basic values held by a person or group regarding the need or not to act from the effective aspect. Cook and Artino (2016) define motivation as a force that comes from within a person that causes that person to take an action. Behavior is influenced by motivation, attitudes and knowledge (Tokan, 2016; Tokan and Imakulata, 2017). Wardani, et al (2020) stated that motivational factors play an important role in academic achievement, because student academic achievement is related to community development. Based on these results, it can be said that the stronger the intrinsic learning motivation, the better the student's learning behavior

\section{b. External Factors}

\section{Family Environment}

Based on the study result, RS parents are the type of parents who do not impose or give freedom to the child's expectations so that the child is free to determine his wishes without any direction that controls the child in his achievement.

This was obtained based on interviews, which stated that their parents rarely accompanied them when studying or doing assignments at home. In addition, parents are easily satisfied with the child's answer stating that there is no homework or homework that the parent should prove by checking the child's record. Apart from that, The hospital has three younger siblings who still need high attention from parents so that parents are not able to give extra attention to all their children excessively. While LT has 1 brother and 1 sister who also both need attention from both parents.

This happens because the parents of the hospital must share the same attention to all their children, besides that the parents of the hospital also need to complete other homework. This also happened to LT where his parents also had to share their attention with their three children who were both still in school, besides that LT's parents had to work. This parenting style is referred to as permissive parenting (Latifah, 2017). With the characteristics of parents applying few expectations or standards of behavior, rarely punishing inappropriate behavior, and allowing children to make their own decisions, it is not uncommon for RS and LT to learn on their own and without being accompanied by parents.

This is in line with the results of Soraya and Khafid's research (2016) which states that there is a positive influence of authoritative parenting on social studies learning achievement, many students get high scores than low scores..

In addition, according to Pratiwi (2013), It is stated that those who have more influence on student learning activities are parents and their own families. This is because the nature of parents, family management applied by parents, family tensions, and family demographics (home location) can have a good or bad impact on learning activities and student outcomes. 


\section{School Environment}

Based on the research result on learning activities carried out in class $\mathrm{V}$, teachers tend not to reflect on the previous material. Syaiful (2013) the purpose of asking questions to students in class about the subject matter that has been given previously is to determine the extent to which the understanding of the material has been given.

The next activity is conveying the learning objectives, in this activity the teacher tends not to convey the learning objectives so that the teacher directly enters the material. In explaining the material, the teacher has been systematic, namely explaining the material from easy to difficult besides that the teacher has also provided opportunities to ask questions. This is in accordance with Hosnan (2014) which states that in questioning activities the teacher tries to open wide opportunities for students to ask questions about what has been seen, listened to, read or seen.

In explaining the material the teacher has been systematic, namely explaining the material from easy to difficult besides that the teacher has also provided opportunities to ask questions. This is in accordance with Hosnan (2014) which states that in questioning activities the teacher tries to open wide opportunities for students to ask questions about what has been seen, listened to, read or seen.

\section{Community Environment}

Based on the research result conducted by interviewing the parents of RS and LT, RS and LT are children who have never been involved in social activities such as organizing, social ativities, or just to socialize. Hospitals, including children, have low socialization skills because hospitals spend more time at home than outside the home. Meanwhile, LT spends most of his time watching TV.

The community's livelihoods around the hospital and LT house are farmers, construction workers, and rice field workers. According to Hasibuan (2011), social factors are more influencing the student's learning process in the form of interfering with the learning process, interfering with student learning tasks, and so on so that when students have many activities outside of learning activities, it will have an impact on low learning achievement.

\section{Dominant Factors Cause Low Learning Achievement}

The most dominant factors behind low learning achievement are intelligence, interest, talent and motivation. In this study, this factor is the most influential intrinsic factor on the low learning achievement of fifth grade students at SDN 1 Barejulat in the 2020/2021 academic year. It has been known previously that interest is a desire, an interest that arises from within. Fadilah (2016) stated that interest can arise because of external attraction and also comes from the heart. While the results of this study indicate the opposite, that students do not have a high interest in learning.

Based on the results of this study, interest in learning is included in the high category. The low interest in learning can be seen from a sense of interest in learning in class, curiosity in several subjects, feeling that they do not have to study every day and lack of diligent study. The tendency of students' low curiosity in several subjects causes learning activities to be less interesting. For this reason, there is a lack of reciprocity during the lesson. Low interest in learning affects students' learning motivation because there is no sense of interest in learning. Because a sense of interest is the beginning of the growth of interest in learning. Based on the information obtained, the class teacher has given a lot of motivation to students and provoked students' curiosity by asking questions at the beginning of the lesson, but it did not make students interested and interested in learning.

The reason students have low interest in learning according to the information obtained is because the location of the school is far away, family conditions do not pay attention to students, and peer relationships do not support student learning activities. 
The schoold's location, which is far from home to far away scholl, requires a long enough vehicle so that it is tiring and students cannot concentrate on their studies. The relationship between parents and children is also very important for children's development, as explained by Pratiwi (2017), namely family relationships are interpreted as an experience process of interacting and communicating with the family environment, especially with parents who teach, train, and provide language examples to children. With the infrequent interaction of students with parents, the relationship is tenuous and there is no warm interaction between parents and children.

Based on the results of research on school condition factors have low criteria. While the results of this study differ from the opinion of the classroom teacher who stated that students have low interest in learning because the school's location is far away. This research was given to class V at SDN 1 Barejulat, so that the dislike of the school where they study is no longer the basis for students to be lazy to participate in learning activities. For the fifth grade students who were the respondents, the fifth grade teacher was fun and motivated and was also close to the students.

Interest is one of the intrinsic factors of learning motivation. Tokan (2016) explains that students who have an interest in a particular topic or activity, and usually those who have an interest will find the topic or activity challenging and interesting. In this case, students have no interest in learning. lack of interest in taking lessons in class is the cause of students getting scores below the KKM. Based on the information obtained, the classroom teacher provides a lot of motivation to learn more about the material that has been given in class, but the student learning outcomes are still not satisfactory.

The low interest in student learning becomes the root of learning difficulties if it is not handled as early as possible. Chulsum (2017) believes that the absence of a child's interest in a lesson will cause learning difficulties. Learning that has no interest may not be in accordance with his talents, not according to his needs, not according to his abilities. The interview results stated that the talent factor stated that there was no high talent for learning. With this condition, the factor of interest in learning is also influenced by factors from the student's environment.

The commitment factor to the task becomes an influence in the low learning achievement. Commitment to the task, sommonly referred to as binding oneself to the task, is an intrinsic factor in learning achievement. Lailana and Handayani (2017) suggest that commitment to a task is an internal motivation that encourages a person to be diligent and tenacious in doing their job despite experiencing various obstacles.

The ability to commit to assignments helps students to be more responsible for their assignments. However, this does not happen in hospitals, hospitals tend to pay less attention to the tasks given by the teacher and tend to work from scratch and the important thing is to finish quickly. The phenomenon of students doing homework at school shows that students do not have the readiness to take part in learning activities in class.

Other factors also influence the reason for the low commitment to student assignments in learning motivation. Such as interest in learning, family conditions, peers, students' self-confidence in doing assignments, and concentration of students participating in learning activities in class. It is known above, that students have low learning achievement due to factors that are interrelated with each other.

\section{Teachers' efforts to improve learning achievement are low}

The teacher's efforts in improving the learning achievement of fifth grade students at SDN 1 Barejulat are efforts to motivate students by creating a thick class atmosphere with the spirit to compete, so that students compete with their friends. For example, after completing daily tests, mid semesters, semester exams and so on. 
Each student is required to memorize the value he has obtained, then when the teacher will input the value, each student is called in order according to attendance and mentions the value he obtained aloud and confidently. So when students hear their friends get higher scores than other students, they want to compete to be better than their friends. Students who have low grades will feel embarrassed so they will study harder or at least they will listen to the teacher's explanation well in class.

Another effort is that the teacher provides additional guidance to students by holding lessons in the afternoon at students' homes. At home, the teacher provides a special opportunity for students to ask questions about materials that they have not understood in the learning process. The fifth grade teacher of SDN 1 Barejulat holds lessons in the afternoon which is carried out twice a week, after the Asr prayer starting at 16.00 until 17.30 WITA, the teacher requires students to take part in these tutoring activities to keep up with the students' misses. The lessons take place in the student's home. The reason the teacher chooses to stay at the student's home is so that the student wants to take additional lessons that have been scheduled

\section{CONCLUSION}

The most dominating factors for low learning achievement are interest in learning, motivation, family environment, school environment, and community environment. The teacher's efforts in improving the learning achievement of fifth graders at SDN 1 Barejulat are efforts to motivate students by creating a thick class atmosphere with the spirit to compete, efforts to guide students by providing additional tutoring for students with low academic achievement.

\section{RECOMMENDATION}

For teachers who still use conventional methods in teaching, it is better for teachers at the time of teaching to be more creative in using learning methods in accordance with the 2013 curriculum, utilizing learning media as learning tools that will make students more active in the learning process.

\section{REFERENCES}

Amri, S. (2018). Pengaruh Kepercayaan Diri (Self Confidence) Berbasis Ekstrakurikuler Pramuka Terhadap Prestasi Belajar Matematika Siswa Sma Negeri 6 Kota Bengkulu. Jurnal Pendidikan Matematika Raflesia, 3(2), 156-170.

Andri, A., Zagir, Z., \& Dores, O. J. (2017). Analisis faktor-faktor yang mempengaruhi rendahnya prestasi belajar siswa pada mata pelajaran matematika di SD Negeri 04 Bati Tahun Pelajaran 2016/2017. Jurnal Pendidikan Dasar Perkhasa: Jurnal Penelitian Pendidikan Dasar, 3(2), 414-426.

Ansori, I., Endang, B., \& Yusuf, A. (2016). Analisis Faktor-Faktor Penyebab Rendahnya Prestasi Belajar Pada Siswa Kelas VIII Sekolah Menengah Pertama. Jurnal Pendidikan dan Pembelajaran Khatulistiwa, 5(10).

Arikunto, S. (2013). Prosedur Penelitian Suatu Pendekatan Praktik. Jakarta: PT Rineka Cipta.

Chulsum, U. (2017). Pengaruh Lingkungan Keluarga, Kedisiplinan Siswa, Dan Motivasi Belajar Terhadap Hasil Belajar Ekonomi Siswa Di SMA Negeri 7 Surabaya. Jurnal ekonomi pendidikan dan Kewirausahaan, 5(1), 5-20.

Cook, D. A., \& Artino Jr, A. R. (2016). Motivation to learn: an overview of contemporary theories. Medical education, 50(10), 997-1014.

Danim, S. (2012). Metode penelitian untuk ilmu-ilmu perilaku [Research methods for the behavioral sciences]. Jakarta, Indonesia: Bumi Aksara.

Fadillah, A. (2016). Analisis minat belajar dan bakat terhadap hasil belajar matematika siswa. Mathline: Jurnal Matematika dan Pendidikan Matematika, 1(2), 113-122. 
Ghozali, I. (2017). Pendekatan Scientific Learning Dalam Meningkatkan Prestasi Belajar Siswa. PEDAGOGIK: Jurnal Pendidikan, 4(1).

Goddard, Y., Goddard, R., \& Kim, M. (2015). School instructional climate and student achievement: An examination of group norms for differentiated instruction. American Journal of Education, 122(1), 111-131.

Gunawan, G., Purwoko, A. A., Ramdani, A., \& Yustiqvar, M. (2021). Pembelajaran Menggunakan Learning Management Systemberbasis Moodle pada Masa Pandemi Covid-19. Indonesian Journal of Teacher Education, 2(1), 226-235.

Hadisaputra, S., Gunawan, G., \& Yustiqvar, M. (2019). Effects of Green Chemistry Based Interactive Multimedia on the Students' Learning Outcomesand Scientific Literacy. Journal of Advanced Research in Dynamical and Control Systems, 11(7), 664-674.

Hasibuan, E. K. (2018). Analisis kesulitan belajar matematika siswa pada pokok bahasan bangun ruang sisi datar di smp negeri 12 bandung. Axiom: Jurnal Pendidikan dan Matematika, 7(1).

Hilda CF, Nahusona MR \& Toto SR (2004). Analysis of factors influencing employee of desire to move (Case Study at PT. Bank Papua). Journal of Management \& Organization Studies, 2:2-10.

Hosnan, M. (2014). Pendekatan saintifik dan kontekstual dalam pembelajaran abad 21. Bogor: Ghalia Indonesia, 456.

Hur, J. W., Shannon, D., \& Wolf, S. (2016). An investigation of relationships between internal and external factors affecting technology integration in classrooms. Journal of Digital Learning in Teacher Education, 32(3), 105-114.

Lailiana, N. A., \& Handayani, A. (2017, June). Motivasi Berprestasi Ditinjau Dari Komitmen Terhadap Tugas Pada Mahasiswa. In Proceedings Education and Language International Conference (Vol. 1, No. 1).

Latifah, N. (2017). Konseling Individual Untuk Meningkatkan Kedisiplinan Siswa Di Sekolah Dengan Cara Pendekatan Behaviour Realita Di Smp Pgri 3 Banjarmasin. Jurnal Mahasiswa BK An-Nur: Berbeda, Bermakna, Mulia, 3(1), 8-12.

Pratiwi, N. K. (2017). Pengaruh tingkat pendidikan, perhatian orang tua, dan minat belajar siswa terhadap prestasi belajar bahasa indonesia siswa smk kesehatan di kota tangerang. Pujangga, 1(2), 31.

Ramdani, A., Jufri, A. W., Gunawan, G., Fahrurrozi, M., \& Yustiqvar, M. (2021). Analysis of Students' Critical Thinking Skills in terms of Gender Using Science Teaching Materials Based on The 5E Learning Cycle Integrated with Local Wisdom. Jurnal Pendidikan IPA Indonesia, 10(2), 187-199.

Rosyid, M. Z., Mansyur, M., IP, S., \& Abdullah, A. R. (2019). Prestasi belajar. Literasi Nusantara.

Rubie-Davies, C. M., Peterson, E., Irving, E., Widdowson, D., \& Dixon, R. (2010). Expectations of achievement: Student teacher and parent perceptions. Research in Education, 83(1), 36-53.

Safitri, F., \& Yuniwati, C. (2019). Pengaruh Motivasi dan Dukungan Keluarga terhadap Prestasi Belajar Mahasiswa Tingkat II Prodi D-III Kebidanan Universitas Ubudiyah Indonesia. Journal of Healthcare Technology and Medicine, 2(2), 154-161.

Sirait, E. D. (2016). Pengaruh minat belajar terhadap prestasi Belajar Matematika. Formatif: Jurnal Ilmiah Pendidikan MIPA, 6(1).

Soraya, A. N., \& Khafid, M. (2016). Pengaruh Kualitas Pola Asuh Orang Tua, Cara Belajar Dan Peran Kelompok Teman Sebaya Terhadap Prestasi Belajar Mata Pelajaran Ekonomi. Economic Education Analysis Journal, 5(2), 560-560.

Sudarsana, I. K. (2016). Peningkatan mutu pendidikan luar sekolah dalam upaya pembangunan sumber daya manusia. Jurnal Penjaminan Mutu, 1(1), 1-14. 
Sutrischastini, A., \& Riyanto, A. (2015). Pengaruh motivasi kerja terhadap kinerja pegawai kantor sekretariat daerah Kabupaten Gunungkidul. Kajian Bisnis Sekolah Tinggi Ilmu Ekonomi Widya Wiwaha, 23(2), 121-137.

Syafi'i, A., Marfiyanto, T., \& Rodiyah, S. K. (2018). Studi tentang prestasi belajar siswa dalam berbagai aspek dan faktor yang mempengaruhi. Jurnal Komunikasi Pendidikan, 2(2), 115-123.

Syaiful, S. (2013). Konsep dan makna pembelajaran untuk membantu memecahkan problematika belajar dan mengajar. Bandung: Alfabeta.

Tokan, M. K. (2016). The behaviour in effort of healthy farming of seaweed farmers in Kupang district. Ecology, Environment and Conservation, 22(4), 1587-1600.

Tokan, M. K., \& Imakulata, M. M. (2017). The effect of the extension method toward behavior in effort of healthy farming of seaweed farmer's in Kupang district. Asian Journal of Microbiology, Biotechnology \& Environmental Sciences, 19(2), 313-321.

Tokan, M. K., \& Imakulata, M. M. (2019). The effect of motivation and learning behaviour on student achievement. South African Journal of Education, 39(1).

Wardani, A. D., Gunawan, I., Kusumaningrum, D. E., Benty, D. D. N., Sumarsono, R. B., Nurabadi, A., \& Handayani, L. (2020, November). Student learning motivation: a conceptual paper. In 2nd Early Childhood and Primary Childhood Education (ECPE 2020) (pp. 275-278). Atlantis Press.

Yustiqvar, M., Hadisaputra, S., \& Gunawan, G. (2019). Analisis penguasaan konsep siswa yang belajar kimia menggunakan multimedia interaktif berbasis green chemistry. Jurnal Pijar Mipa, 14(3), 135-140.

Zhu, Y., \& Yang, J. (2012). Effects of farmers' motivation on their participation in publicly funding training programs in Sichuan Province, China. Journal of Agricultural Science (Toronto), 4(10), 68-74. 